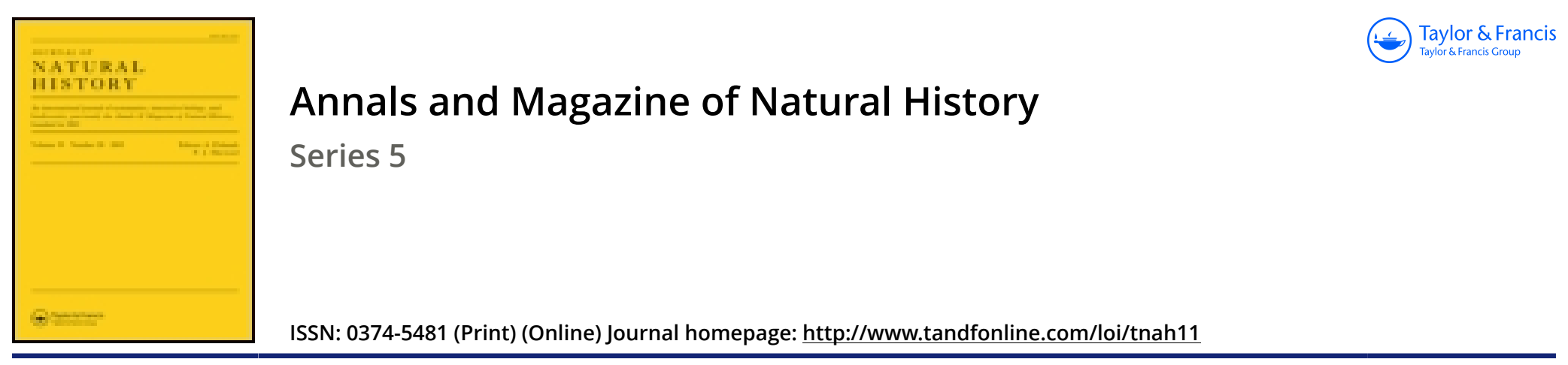

\title{
On the structure of the branchia of the Prosbranchiate Gasteropods
}

\section{Félix Bernard}

To cite this article: M. Félix Bernard (1887) On the structure of the branchia of the Prosbranchiate Gasteropods, Annals and Magazine of Natural History, 20:117, 247-249, DOI: 10.1080/00222938709460045

To link to this article: http://dx.doi.org/10.1080/00222938709460045

$$
\text { 曲 Published online: } 07 \text { Oct } 2009 .
$$

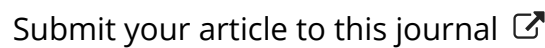

Џ Article views: 1 
The following form I name with some hesitation; for although Mr. Meyrick, to whom I showed it, expressed his opinion that it was distinct from $S$. urapterina, I still feel some doubt about it*.

\section{Strophidia hyemalis, sp. $\mathrm{n}$.}

$\delta q$. Quite like a small edition of $S$. urapterina, but with the brown bands slightly paler, more oblique, narrower, and of more equal width; no short brown stripe at the end of the cell of primaries. Expanse of wings 44 millim.

'T'wo examples. Alu, Shortland Island.

$S$. urapterina from the same island measures 58 millim. in expanse of wing, and differs in no respect from the typical New-Ireland form.

\section{Larentiidø.}

13. Remodes volcanica, sp. $\mathrm{n}$.

Primaries dark greenish sulphur or mustard-yellow, crossed by five bands, the first two indistinct, formed of about three olivaceous stripes which converge and unite in a brown spot on the submedian vein; third band wider, more distinct, formed of three wavy parallel stripes marked with brown beyond the cells and towards inner margin; fourth band formed of two similarly-marked stripes; fifth band or external border olivaceous, with black-spotted zigzag inner edge; outer margin with six black spots placed alternately with the submarginal series ; fringe pale yellow, tipped with olivaceous: secondaries sericeous greyish brown; fringe slightly yellowish at base: thorax greenish yellow; antennæ brownish ; abdomen whity brown, with greenish dorsal region. Under surface pale sericeous brownish grey; pectus, femora, and tibiæ yellow, tarsi dark brown. Expanse of wings 42 millim.

Shortland Island.

\section{MISCELLANEOUS.}

On the Structure of the Branchia of the Prosobranchiate Gasteropods. By M. Féltx Berrard.

Mr investigations have been directed to numerous genera belonging to varions families of Sentibranchiata, Tænioglossa, Rhachiglossa, and Toxiglossa. They have enabled me to study in detail the

* I quote my friend Meyrick's authority here because in the matter of speces be is rather inclined to assuciate allied forms under one specific name, sometimes to an extent that is perfectly astounding. 
elements which compose the branchial lamollæ, and to establish the identity of the structure of these organs in all tho types examined, whether they belong to the type of unipennate branchiæ or to that of bipennate branchiæ.

1. The epithelium of the branchia always appears formed of two kinds of elements-of columnar cells inserted upon the basal membrane by a slender, sometimes ramified process, and terminated at the other end by a ciliated disk; the disks of contiguous cells touch one another, so as to form a regular and continuous mosaic, beneath which, between the groups of the preceding cells, occur small sphorical or ovoid masses of muciparous cells. The epithelium of the mantle and of the false branchia also presents these two kinds of elements.

2. The basal membrane of the epithelium forms upon each surface, along the inner margin in the unipennate branchix, a resistant thickening of triangular section, which is the supposed supporting cartilaginous rod. This thickening is formed of superposed layers and presents no trace of cells. It is therefore not cartilage, as has so often been said.

3. Between the two laminæ of the basal membrane there are stellate cells with anastomosing processes, sometimes isolated, sometimes collected into groups, especially near the margins, where they are sometimes arranged with regularity. This is the ordinary connectice tissue of the lacunæ.

4. A bundle of longitudinal museular fibres extends quite to the point; from it are detached fibres which run obliquely towards the outer margin.

Other fibres, transverse and often distinctly ramified at their extremity, are less constant in their occurrence and arrangement. This is the case also with another system of Iongitudinal fibres, sometimes forming a close grating with the preceding. All these fibres meet on both sides of the central lacuna.

The innervation of the branchia compared with that of the false branchia will be the subject of another communication.

With regard to the circulation, I have been led to resume the recent researches of MM. Wegmann and Boutan. These anatomists have indicated, one of them in Haliotis, the other in Fissurella, the existence of vessels in each margin of the lamella and united by transverse capillaries. Numerous injections, sections, and transparent preparations obtained by removing the epithelium by reagents enable me to assert that in these two genera, as in all those which I have hitherto studied, there are neither vessels nor capillariesthat is to say, there is no canal circumscribed by a muscular or endothelial coat.

According to M. Boutan *, " the lamellæ are formed of a spongy tissue filled with little lacunæ, the excessirely minute size of which must cause them to bo assimilated to capillaries." Now any assimilation of lacunw, however small they may be, to capillaries,

* Arch. de Zonl. experr. sér. 29, tome iii., Suppl. p. 37. 
seems to me contrary to what we know most precisely of the morphology of the circulatory apparatus.

On the other hand, M. Wegmann had previously figured $*$ and described, in more detail than M. Boutan, a complicated system of capillary vessels in Hatiotis. Now H. Milne-Edwards long ago announced that the organs of the Gastcropoda (except perhaps the renal organ) always present lacunæ and no capillaries. It was therefore interesting to ascertain whether the branchia formed an exception to this rule.

By injections I have had no difficulty in reproducing the appearances figured by $M$. Wegmann; but I explain them by the wellknown foldings of the lamella and also by the nearly regular arrangement in line of the connective cells or groups of such cells. The supposed vessels of the two margins are only portions of the lacuna in which the connective tissue is sparse and in which, consequently, the injected material circulates easily.

'The space wittin the double basal membrane is therefore nothing but a simple diverticulum of the general lacuna, which extends between the two laminæ of tho mantle. My investigations thus confirm the views of Milne-Edwards.

I may add that in the Aplysiidæ and Bullidæ the branchia is formed by the more or less complicated folding of a single lamella, the structure of which is the same as that just described for the pectinate branchiæ.-Comptes Rendus, August 8, 1887, p. 316.

Description of a newly-excluded Young of the Ornithorhynchus paradoxus. By Sir Ricmard Owen, K.C.B., F.R.S., \&c.

Of this interesting and long-hoped-for discovery the author was informed by his friend and correspondent, the Baron von Müller, F.R.S., of the Botanical Gardens, Məlbourne, and shortly received the specimen from the Baron: also further details from Mr. Le Souef, of the Zoological and Acclimatisation Society's Office, Melbourne; and from the Rev. Pastor Hagenauer, Superintendent of the Missionary Station in Gipps-Land, S.E. Victoria, to whose influence with the natives science is indebted for the acquisition, as I am to Baron von Miiller for the reception, of the embryo well preserved in alcohol. The specimen is nude, an inch in length, the nostrils well opened, und between them the fleshy conical support of the horny sheath, which has been shed and by which the chorion had been torn open at birth. The mouth is a transverse slit, not produced as a beak, bounded by flexible lips, and sufficiently open to receive nutriment afforded by the group of pores excluding the secretion of the mammary gland of the pouch. The fore limbs, chiefly represented by the paws and pentadactyle, with claws sufficiently developed for adhering to the part of the pouch on which the excretory pores open. The hind limbs are less developed, have

* Ibid. sér. 2, tome ii. pl. xix.

Ann. \& Mag. N. Hist. Ser. 5. Vol. xx. 